\title{
An investigation of ring and dicentric chromosomes found in three Turner's syndrome patients using DNA analysis and in situ hybridisation with $\mathrm{X}$ and $\mathrm{Y}$ chromosome specific probes
}

\author{
C Cooper, J A Crolla, C Laister, D I Johnston, P Cooke
}

\begin{abstract}
We have studied three patients with features of Turner's syndrome, two with a $45, X / 46, X, r(?)$ and the third with a $45, X / 46, X, d i c ?(Y)$ karyotype. Because Turner's syndrome patients with a mosaic karyotype containing a $Y$ chromosome are known to have a high risk of developing gonadal tumours, we used DNA analysis and in situ hybridisation with $X$ and $Y$ specific probes to identify the chromosomal origin of the rings and dicentric chromosomes in the three index patients. Both ring chromosomes were shown to be of $X$ origin, while the dicentric was composed of $\mathbf{Y}$ chromosome material. We discuss the importance of using a combination of molecular and cytogenetic analyses in such cases.
\end{abstract}

One of the consequences of Turner's syndrome is abnormal gonadal development in females. Patients

Department of Cytogenetics, City Hospital, Hucknall Road, Nottingham NG5 1PB.

C Cooper, C Laister

Wessex Regional Genetics Laboratory, Salisbury Royal Infirmary, Salisbury.

J A Crolla

Department of Paediatric Medicine, Queen's Medical Centre, Nottingham.

D I Johnston

Trent Regional Health Authority, Fulwood House, Old Fulwood Road, Sheffield.

P Cooke

Correspondence to Mrs Cooper.

Received for publication 8 March 1990

Revised version accepted for publication 21 June 1990. with Turner's syndrome can present with a variety of chromosome complements and only $50 \%$ have a $45, \mathrm{X}$ karyotype alone. A cell line with a $\mathrm{Y}$ chromosome is present in $5.5 \%$, and a further $3 \%$ of cases have an unidentifiable marker chromosome presumably derived from an $\mathrm{X}$ or $\mathrm{Y}$ chromosome. ${ }^{1}$

Patients with mosaicism involving a $\mathrm{Y}$ chromosome are a clinically important subgroup because they have a 15 to $20 \%$ risk of developing gonadoblastoma or dysgerminoma ${ }^{2}$; these tumours rarely occur in Turner's syndrome patients without a $\mathrm{Y}$ chromosome. ${ }^{3}$ Therefore, it is important to establish unequivocally the origin (X or $\mathrm{Y}$ ) of marker chromosomes found in Turner's syndrome patients, something which is often difficult to achieve consistently using conventional cytogenetic ( $G$ or $G 11$ banding) methods. ${ }^{45}$

The availability of $\mathrm{X}$ and $\mathrm{Y}$ specific DNA probes has made it possible by DNA and in situ hybridisation analyses to detect the presence of $\mathrm{Y}$ chromosome material in patients with sex chromosome abnormalities, including small rings. ${ }^{5-7}$ By using a combination of conventional cytogenetic methods, in situ hybridisation, and DNA analyses, we have studied two patients with a 45,X/46,X,r(?) karyotype and one patient with a $45, \mathrm{X} / 46, \mathrm{X}$,dic?(Y) karyotype, and determined the chromosomal origin of the ring or dicentric chromosome in each case.

\section{Materials and methods}

CASE 1

Case 1 presented at the age of 15 years 1 month because of short stature and delayed puberty. Her height was $142.4 \mathrm{~cm}(-3.3 \mathrm{SD})$. She had other features suggestive of Turner's syndrome including widely spaced nipples, an increased carrying angle, 
and multiple cutaneous naevi. Raised basal gonadotrophin levels were present with luteinising hormone (LH) of $47 \mathrm{IU} / 1$ and follicular stimulating hormone (FSH) greater than $80 \mathrm{IU} / 1$. Pelvic ultrasound defined a uterus but no gonadal tissue.

CASE 2

Case 2 presented at the age of 9 years 9 months because of short stature; her height was $117 \cdot 3 \mathrm{~cm}$ $(-3.0 \mathrm{SD})$. Her parents were short and she had been of low birth weight at $2100 \mathrm{~g}$. No dysmorphic features indicative of Turner's syndrome were present. Other investigations found LH to be $5.9 \mathrm{IU} / 1$ and FSH 77 IU/l. Pelvic ultrasound showed a uterus $2 \mathrm{~cm}$ long but no identifiable gonadal tissue.

CASE 3

Case 3 presented at the age of 12 years 5 months because of short stature and behavioural problems. Her height was $133.4 \mathrm{~cm}(-3.4 \mathrm{SD})$. She had features. suggestive of Turner's syndrome including characteristic facies, widely spaced nipples, increased carrying angle, and multiple cutaneous naevi. Basal gonadotrophins were not raised (LH $<1$ IU/1 and FSH 6 IU/l). Pelvic ultrasound defined a uterus but no gonadal tissue.

\section{CYTOGENETICS}

Cytogenetic analysis was carried out on metaphases obtained from phytohaemagglutinin (PHA) stimulated peripheral lymphocytes using standard techniques. Initial chromosome analysis was performed using GTG banded metaphases ${ }^{8}$ and subsequently metaphases were CBG banded. ${ }^{9}$

PROBES

Cosmid Y84 was originally isolated from a human Y chromosome library and contains three copies of a 5.5 $\mathrm{kb} E$ coRI repeat. ${ }^{10}$ In conditions of high washing stringency, it strongly hybridises to the $5.5 \mathrm{~kb} E c o \mathrm{RI}$ fragment characteristic of the alphoid centromeric repeat of the human $\mathrm{Y}$ chromosome. ${ }^{10}$

Probe p75/79 was derived from a subclone of cosmid 75 isolated from a $\mathrm{Y}$ chromosome library and hybridises to a $\mathrm{Y}$ specific $2 \mathrm{~kb}$ fragment located between Ypter and Yq11. ${ }^{11}$ Y190 hybridises in situ to the Yp proximal heterochromatin ${ }^{12}$ and $\mathrm{pSV} 2 \mathrm{X} 5$ is derived from an alphoid $X$ centromere specific sequence cloned into pSV2Neo. ${ }^{10}$

\section{DNA PREPARATION AND IN SITU HYBRIDISATION}

Genomic DNA was prepared from peripheral blood of the three patients and normal male and female controls. DNA extraction, enzyme digestion, and Southern blotting were carried out by modifications of standard procedures described elsewhere. ${ }^{13}{ }^{14}$ For in situ hybridisation, biotinylated probes were hybridised overnight to standard metaphase spreads, washed at high stringency, and the sites of hybridisation detected using a double antibody amplification

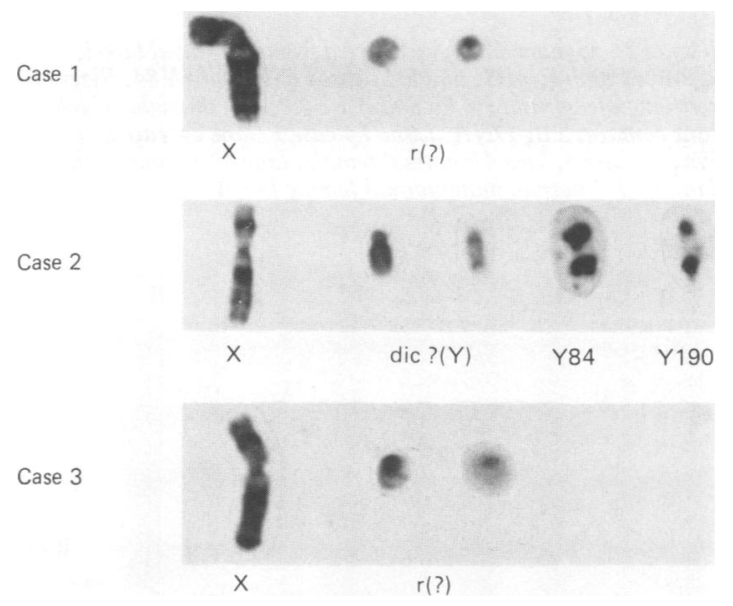

Figure 1 GTG banded X chromosome and GTG (left) and $C B G$ (right) banded ring and dicentric chromosomes from each case. The dicentric chromosome present in case 2 is shown after in situ hybridisation with probes Y84 and Y190.

Results of chromosome analysis, DNA analysis, and in situ hybridisation (numbers of metaphases studied given in brackets).

\begin{tabular}{|c|c|c|c|c|c|c|}
\hline \multirow[b]{2}{*}{ Case 1} & \multirow{2}{*}{$\begin{array}{l}\text { Karyotype } \\
\begin{array}{l}45, \mathrm{X} / 46, \mathrm{Xr}(?) \\
(16)(8)\end{array}\end{array}$} & \multicolumn{2}{|c|}{ DNA analysis } & \multicolumn{3}{|c|}{$\begin{array}{l}\text { In situ hybridisation analysis } \\
\text { of ring/dicentric chromosomes }\end{array}$} \\
\hline & & $\begin{array}{l}\text { Y84 } \\
\text { (Ycen) } \\
-\end{array}$ & $\begin{array}{l}\text { p75/79 } \\
(\mathbf{Y p}) \\
-\end{array}$ & $\begin{array}{l}\text { pSV2X5 } \\
(\mathrm{Xcen})^{*} \\
46, \mathrm{X}, \mathrm{r}(\mathrm{X}) \\
(7)\end{array}$ & $\begin{array}{l}\text { Y84 } \\
\text { (Ycen)† }\end{array}$ & $\begin{array}{l}\text { Y190 } \\
(\mathrm{Yp})\end{array}$ \\
\hline Case 2 & $\begin{array}{l}45, X / 46, X, \operatorname{dic} ?(Y) \\
\text { (5) (15) }\end{array}$ & + & + & & $\begin{array}{l}\text { 46,X, } \operatorname{dic}(Y) \\
(7)\end{array}$ & $\begin{array}{l}46, X, \operatorname{dic}(Y) \\
(12)\end{array}$ \\
\hline Case 3 & $\begin{array}{l}45, \mathrm{X} / 46, \mathrm{Xr}(?) \\
(14)(6)\end{array}$ & - & - & $\begin{array}{l}46, X, r(X) \\
(15)\end{array}$ & & \\
\hline
\end{tabular}

*The normal $X$ acted as an internal control for $X$ centromere specific signal.

†Normal 46,XY control slides were processed under the same experimental conditions in order to check the efficiency and specificity of the $Y$ specific probes. 
step followed by precipitation of diaminobenzidine onto an avidin-horseradish peroxidase complex in the presence of hydrogen peroxide. Full details of the in situ technique have been published elsewhere. ${ }^{15}$

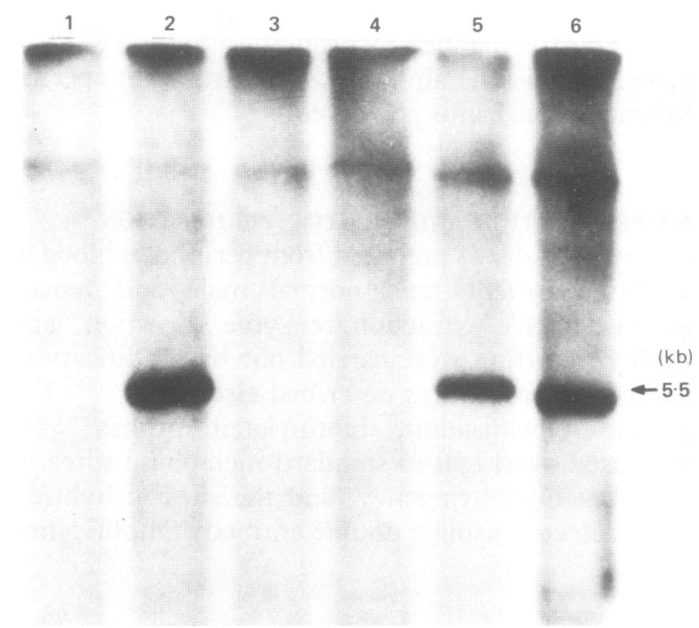

Figure 2 Genomic DNA extracted from peripheral blood, restricted with EcoRI, and hybridised with probe Y84. Sizes of restriction fragments (in $k b$ pairs) are given on the right. Each lane contains 5 ug DNA. Lane $1=$ case 1 , lane $2=$ case 2 , lane 3=case 3, lane 4=normal female, lane 5=normal male, lane $6=1: 1$ normal male:normal female DNA.

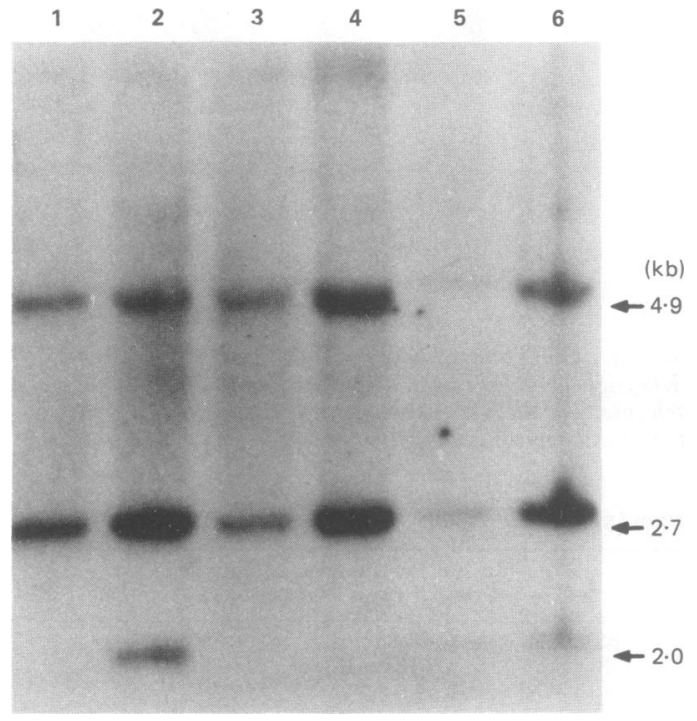

Figure 3 Genomic DNA extracted from peripheral blood, restricted with EcoRI, and hybridised with p75/79. Sizes of restriction fragments (in $k b$ pairs) are given on the right. Each lane contains $5 \mu \mathrm{g}$ DA. Lane $1=$ case 1 , lane $2=$ case 2 , lane $3=$ case 3 , lane $4=$ normal female, lane $5=$ normal male, lane $6=1: 1$ normal male:normal female DNA.

\section{Results}

Detailed results of the cytogenetic, DNA, and in situ hybridisation analyses are shown in the table and figs 1 to 3. Cytogenetic analysis of the father of case 2 (dic?Y) showed an apparently normal GTG banded and CBG banded $Y$ chromosome. Fig 1 shows the GTG and CBG banded appearance of the ring and dicentric chromosomes of each patient.

Southern blotting and hybridisation with Y84 and p75/79 showed that the $\mathrm{Y}$ specific $5.5 \mathrm{~kb}$ EcoRI fragment detected by Y84 and the $2.0 \mathrm{~kb}$ Y specific fragment detected by p75/79 are both absent in cases 1 and 3 but present in case 2 (figs 2 and 3).

Probes p75/79 and Y84 were hybridised to artificial mixtures of normal male and female DNA (results not shown). The $Y$ specific $2.0 \mathrm{~kb}$ (p75/79) and $5.5 \mathrm{~kb}$ (Y84) fragments were visible, though faint, when male DNA comprised as little as $5 \%$ of the total mixture.

In situ hybridisation with probe $\mathrm{pSV} 2 \mathrm{X} 5$ on cases 1 and 3 gave two discrete signals, one from the structurally normal $X$ and the other from the ring chromosome. In situ hybridisation on case 2 with probes Y190 and Y84 showed two strong signals from the dic?(Y), both distally located (fig 1).

\section{Discussion}

At high washing stringency, probe $\mathrm{Y} 84$ hybridises to a $5.5 \mathrm{~kb} E c o$ RI fragment specific to the alphoid centromeric repeat of the $\mathrm{Y}$ chromosome. ${ }^{10} \mathrm{~A}$ centromeric probe is useful in cases where a cytogenetically unidentifiable ring or dicentric chromosome is suspected to be derived from a $\mathrm{Y}$ chromosome, as sequences which map to distal Yp or Yq may be lost during the formation of these chromosomes, although their centromeric sequences are preferentially retained.

Our hybridisation results using Y84 and p75/79 to a panel of artificial mixtures of normal male and female DNA suggest that each probe can be used to detect $Y$ chromosome sequences at a frequency of $>5 \%$ male DNA. As the dicentric chromosome in case 2 is present at a frequency of approximately $75 \%$ (SD $10 \%$ ), and the ring chromosomes in cases 1 and 3 are present at a frequency of approximately $30 \%$ (SD $10 \%$ ), we conclude that, under the conditions of stringency outlined above, probes Y84 and p75/79 hybridise to $\mathrm{Y}$ chromosome sequences with sufficient sensitivity to detect or exclude these sequences in each of our three patients.

The results presented in the table and figs 2 and 3 unequivocally show that the $\mathrm{Y}$ specific sequences recognised by probes $\mathrm{Y} 84$ and $\mathrm{p} 75 / 79$ are present in case 2 but absent in cases 1 and 3. These results are confirmed by the in situ hybridisation studies where probes $\mathrm{Y} 84$ and $\mathrm{Y} 190$ hybridised to the dic?(Y) in case 2 , giving two strong distally located signals. In cases 1 
and 3 the $\mathrm{X}$ centromere specific probe $\mathrm{pSV} 2 \mathrm{X} 5$ showed specific hybridisation signals to both the small ring chromosomes and the normal $\mathrm{X}$ chromosomes, thus confirming that the small ring chromosome present in both of these patients is derived from the $\mathrm{X}$ chromosome.

The increased risk (15 to $20 \%$ ) of gonadal malignancy in patients with $45, \mathrm{X} / 46, \mathrm{XY}$ or $45, \mathrm{X} / 46, \mathrm{X}$, $\operatorname{dic}(\mathrm{Y})$ karyotypes is well documented, ${ }^{316} 17$ although the number of patients from which these risk estimates are derived is small. As it is known that the prevalence of tumours in patients with a 45, $\mathrm{X}$ cell line and a cell line with a structurally abnormal $\mathrm{X}$ is low, ${ }^{18}$ the results presented above indicate that case 2 has an increased risk of developing gonadoblastoma or dysgerminoma, while cases 1 and 3 have a low risk of developing these tumours.

In conclusion, using a combination of conventional cytogenetic methods, in situ hybridisation, and DNA analysis, we have unequivocally established the origin ( $\mathrm{X}$ or $\mathrm{Y}$ ) of the ring and dicentric chromosomes in each of our three cases and have been able to assign a low risk (cases 1 and 3) or an increased risk (case 2) of malignancy to each patient. We advocate that such molecular studies are undertaken in similar cases as an aid to the clinical management of these patients.

We are grateful to Dr G Cross for his assistance, comments, and suggestions and to Dr P Goodfellow for providing probes pSV2X5, Y84, and p75/79. We thank Mrs B Herod for her assistance with the manuscript.

1 Magenis RE, Breg WR, Clark KA, et al. Distribution of sex chromosome complements in 651 patients with Turner's syndrome. Am f Hum Genet 1980;32:79A.
2 Scully RE. Gonadoblastoma. A review of 74 cases. Cancer 1970;25:1340-55.

3 Simpson JL, Photopulos G. The relationship of neoplasia to disorders of abnormal sexual differentiation. Birth Defects 1976;12(1):15-50.

4 Magenis E, Donlon T. Non-fluorescent Y chromosome. Cytologic evidence of origin. Hum Genet 1982;60:133-8.

5 Crolla JA, Llerena JC. A mosaic 45,X/46,X, r(?) karyotype investigated with $X$ and $Y$ centromere-specific probes using a non-autoradiographic in-situ hybridisation technique. Hum Genet 1988;81:81-4.

6 Stalvey JRD, Erickson RP, Dasouki M, et al. Clarification of chromosomal abnormalities associated with sexual ambiguity by studies with Y-chromosomal DNA sequences. Cytogenet Cell Genet 1988;47:140-3.

7 Kumuidini D, Shah MD, Kaffe S, et al. Unilateral microscopic gonadoblastoma in a prepubertal Turner mosaic with $Y$ chromosome material identified by restriction fragment analysis. Am $\mathcal{F}$ Clin Pathol 1988;90:622-7.

8 Seabright $M$. The use of proteolytic enzymes for the mapping of structural rearrangements in the chromosomes of man. Chromosoma 1972;36:204-10.

9 Sumner AT. A simple technique for demonstrating centromeric heterochromatin. Exp Cell Res 1972;75:304-6.

10 Wolfe J, Darling SM, Erikson RP, et al. Isolation and characterisation of an alphoid centromeric repeat family from the human Y chromosome. F Mol Biol 1985;182:477-85.

11 Wolfe J, Erikson RP, Rigby PWJ, Goodfellow PN. Cosmid clones derived from both euchromatic and heterochromatic regions of the human Y chromosome. EMBO f 1984;3:19972003.

12 Muller U, Donlon TA, Kunkle SM, Lalande M, Latt SA. Y-190, a DNA probe for the sensitive detection of Y-derived marker chromosomes and mosaicism. Hum Genet 1987;87:109-13.

13 Southern EM. Detection of specific sequences among DNA fragments separated by gel electrophoresis. $\mathcal{F}$ Mol Biol 1975;98: 503-17.

14 Kunkel LM, Smith KD, Boyer SJ, et al. Analysis of human Y-chromosome-specific reiterated DNA in chromosome variants. Proc Natl Acad Sci USA 1977;74:1245-9.

15 Crolla JA. Non-isotopic in situ hybridisation immunocytochemical detection of specific repetitive sequences on chromosomes and interphase nuclei. In: Manson MM, ed. Methods in molecular biology: immunochemical techniques. Humana Press (in press).

16 Manuel M, Katayama PK, Jones HW. The age of occurrence of gonadal tumours in intersex patients with a Y chromosome. Am J Obstet Gynecol 1976;124:293-300.

17 Wolman SR, David R, Koo GC. The "Y" chromosome in the female phenotype. In: The $Y$ chromosome. Part A. Basic characteristics of the $Y$ chromosome. New York: Alan $R$ Liss, 1985:477-505.

18 Verp MS, Simpson JL. Abnormal sexual differentiation and neoplasia. Cancer Genet Cytogenet 1987;25:191-218. 